${ }_{354}$ Shorter Contributions

to General Geology

1959

نัj

\%

8

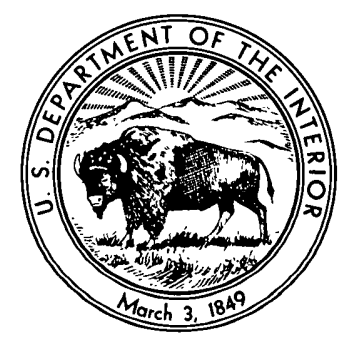

$\frac{2}{4}$

P

资

$\frac{1}{0}$

UNITED STATES GOVERNMENT PRINTING OFFICE, WASHINGTON : 1961 


\section{UNITED STATES DEPARTMENT OF THE INTERIOR}

STEWART L. UDALL, Secretary

GEOLOGICAL SURVEY

Thomas B. Nolan, Director 


\section{CONTENTS}

[The letters in parentheses preceding the titles designate separately published chapters]

Page

(A) Intrenched meanders of the North Fork of the Shenandoah River, Virginia, by John T. Hack and Robert S. Young.

(B) Interpretation of the composition of trioctahedral micas, by Margaret D. Foster........................

(C) Giant waves in Lituya Bay, Alaska, by Don J. Miller

(D) Early Cretaceous (Albian) Ammonites from the Chitina Valley and Talkeetna Mountains, Alaska, by Ralph W. Imlay

(E) Interpretation of the composition of lithium micas, by Margaret D. Foster.
(F) Zones and zonal variations in welded ash flows, by Robert L. Smith.

1 (G) Deposition of uranium in salt-pan basins, by Kenneth G. Bell _.

11 (H) Foraminifera from Onotoa Atoll, Gilbert Islands, by

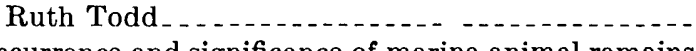

51 (I) Occurrence and significance of marine animal remains in American coal balls, by Sergius H. Mamay and Ellis L. Yochelson. .

(J) Lituyapecten (new subgenus of Patinopecten) from Alaska and California, by F. Stearns MacNeil...-

(K) Stratigraphic Occurrence of Lituyapecten in Alaska, by Don J. Miller.....
Page

149

161

171

241 


\section{Intrenched Meanders of the}

\section{North Fork of the Shenandoah}

\section{River, Virginia}

GEOLOGICAL SURVEY PROFESIONAL PAPER 354-A

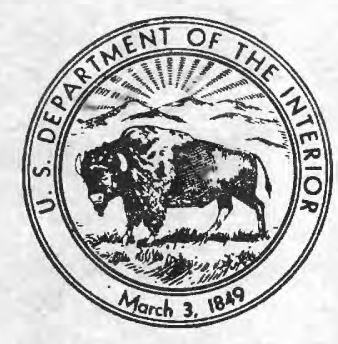




\section{Intrenched Meanders of the}

\section{North Fork of the Shenandoah}

River, Virginia

By JOHN T. HACK and ROBERT S. YOUNG

SHORTER CONTRIBUTIONS TO GENERAL GEOLOGY

GEOLOGICAL SURVEY PROFESSIONAL PAPER 354-A

A study of the channel of a river

intrenched in hard rocks

and an analysis of factors

that cause it to meander

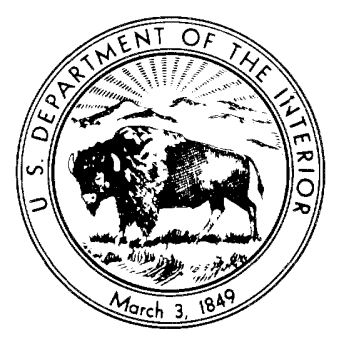

UNITED STATES GOVERNMENT PRINTING OFFICE，WASHINGTON : 1959 


\section{UNITED STATES DEPARTMENT OF THE INTERIOR}

FRED A. SEATON, Secretary

GEOLOGIGAL SURVEY

Thomas B. Nolan, Director

For sale by the Superintendent of Documents, U.S. Government Printing Office Washington 25, D.C. - Price 20 cents (paper cover) 


\section{CONTENTS}
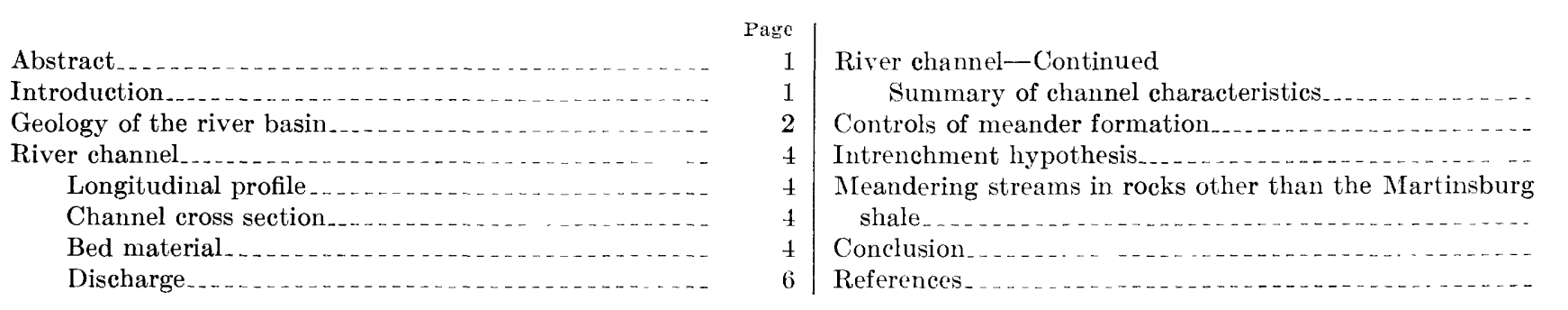

Page

6

6

7

9

9

References $\ldots \ldots \ldots \ldots \ldots$

\section{ILLUSTRATIONS}

Plate 1. Outcrops of Martinsburg shale. A, Uutcrop near Woodstock showing typical beds of fine sandstone and siltstone alternating with shale; $B$, Outerop near Edinburg showing typical prismatic cleavage cutting a spheroid _.. Facing 6

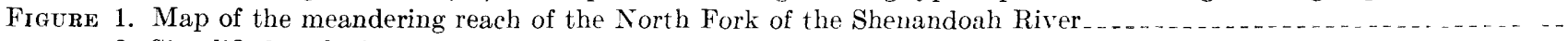

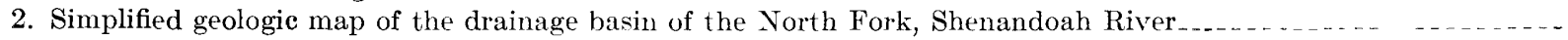

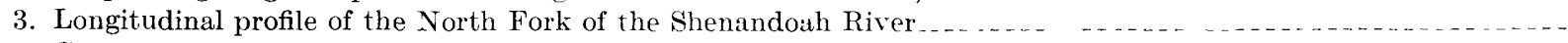

4. Graph on logarithmic scales comparing the dimensions of the channel of the North Fork at different places along the stream_ _

5. Profiles of valley floor

\section{TABLES}

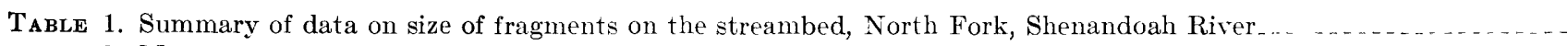

2. Mean annual discharge at gaging stations on the North Fork of the Shenandoah River. 


\title{
INTRENGHED MEANDERS OF THE NORTH FORK OF THE SHENANDOAH RIVER, VIRGINIA
}

\author{
By Johy T. Hack and Robert S. Young ${ }^{1}$
}

\begin{abstract}
The North Fork of the Shenandoah River traverses rocks of different lithology in areas of greatly different topography. The spectacular meanders in which the river travels 3.2 times as far as the direct down valley distance coincide with the outcrop area of a belt of Martinsburg shale. Along the entire river the channel is adjusted to carry bed material of approximately uniform size, and passes through the meandering reach without significant change in channel cross section. The profile of the stream follows a simple logarithmic curre from source to mouth. The upland on either side of the stream, however, slopes downstream at a grade much steeper in the area of the meanders than in the nonmeandering area upstream. It is concluded that the meanders are caused by strong planar and prismatic structures in the Martinsburg shale that favor northwest-southeast differential erosion. The topography of the adjacent upland is graded to the present river. There is no reason to believe that the river has been intrenched from an erosion surface on which the relief was less than that of the present upland or that changes in base level have influenced the meancler development.
\end{abstract}

\section{INTRODUCTION}

The North Fork of the Shenandoah River, Va., is a classic example of a meandering stream intrenched in hard rocks. Photographs of these meanders hare appeared in several textbooks of geology and geomorphology (Thompson, 1947, p. 175 ; Monnett and Brown. 1950 , p. 110; Thornbury, 1954, p. $1 \pm 6$ ). The meanders are prominently displayed in an illustration in a paper by Rich (1939) describing a section across the Appalachians. Butts (1940, p. 508) offers an interpretation of the origin of the meander belt, and Fisher (1955) describes the physical character of the meanders.

A similar meander belt on Conodoguinet Creek, near Harrisburg, Pa., has received at least an equal amount of attention as an example of an intrenched stream and has been studied by Strahler (1946).

Most authors who mention either of these meandering streams imply that they are inherited from a surface of low relief and were intrenched into the valley floor during rejuvenation, as a consequence of uplift or change in base level. As pointed out by Thornbury, however (1954, p. 145), geomorphologists are not

\footnotetext{
1 University of Virginia, formerly of the Virginia Division of Geology (now the Virginia Division of Mineral Resources).
}

agreed that all intrenched meanders have been formed in this way. For example, Cole (1930) has shown that meanders may form in hard rocks by erosion along joint planes. Gregory and Moore (1931, p. 136) believe that many of the meanders that are spectacular features of the Colorado Plateau region were formed by lateral corrasion of the hard rock strata.

The writers believe that the meandering reach of the North Fork of the Shenandoah River is simply a river segment with a smooth and regular profile, adjusted for the transportation of a certain load. The enclosing rocks have special characteristics faroring erosion in a preferred direction, and the adjusted channel slope is maintained in spite of the increase in sinuosity. To (hange in base level is necessarily involved in the formation of the meanders.

The meandering reach of the North Fork is shown in figure 1, a map prepared from the Strasburg and Edinburg quadrangles of the U.S. Geological Survey. The reach begins at Edinburg and ends at Strasburg, It miles downvalley. The sinuosity (the distance measured along the stream, divided by the distance measured along the valley) attains the remarkably high value of 3.2. The narrom valley bottom is 100 to 150 feet below the general level of the adjacent shale hills. Measured along the channel, the river has an average gradient of 5.5 feet per mile, whereas the valley floor. measured across the hilltops between the bends, has a gradient of 17 feet per mile. As shown on the geologic map, figure 2 , the meander belt is localized within the outcrop area of the Martinsburg shale (Ordovician). This formation, as described on page 6 , is lithologically unique in the region and its close relation to the meanders led the writers to undertake this study. The relation is not confined to the North Fork; similar meanders occur in other areas of Martinsburg shale, as on the Middle River, Angusta County, Va., and on Conococheague Creek, Washington County, Md. In these areas the meandering reaches correspond closely to the limits of the same formation.

The writers' work on the Shenandoah River grew out of hedrock geologic mapping by R. S. Young in the 


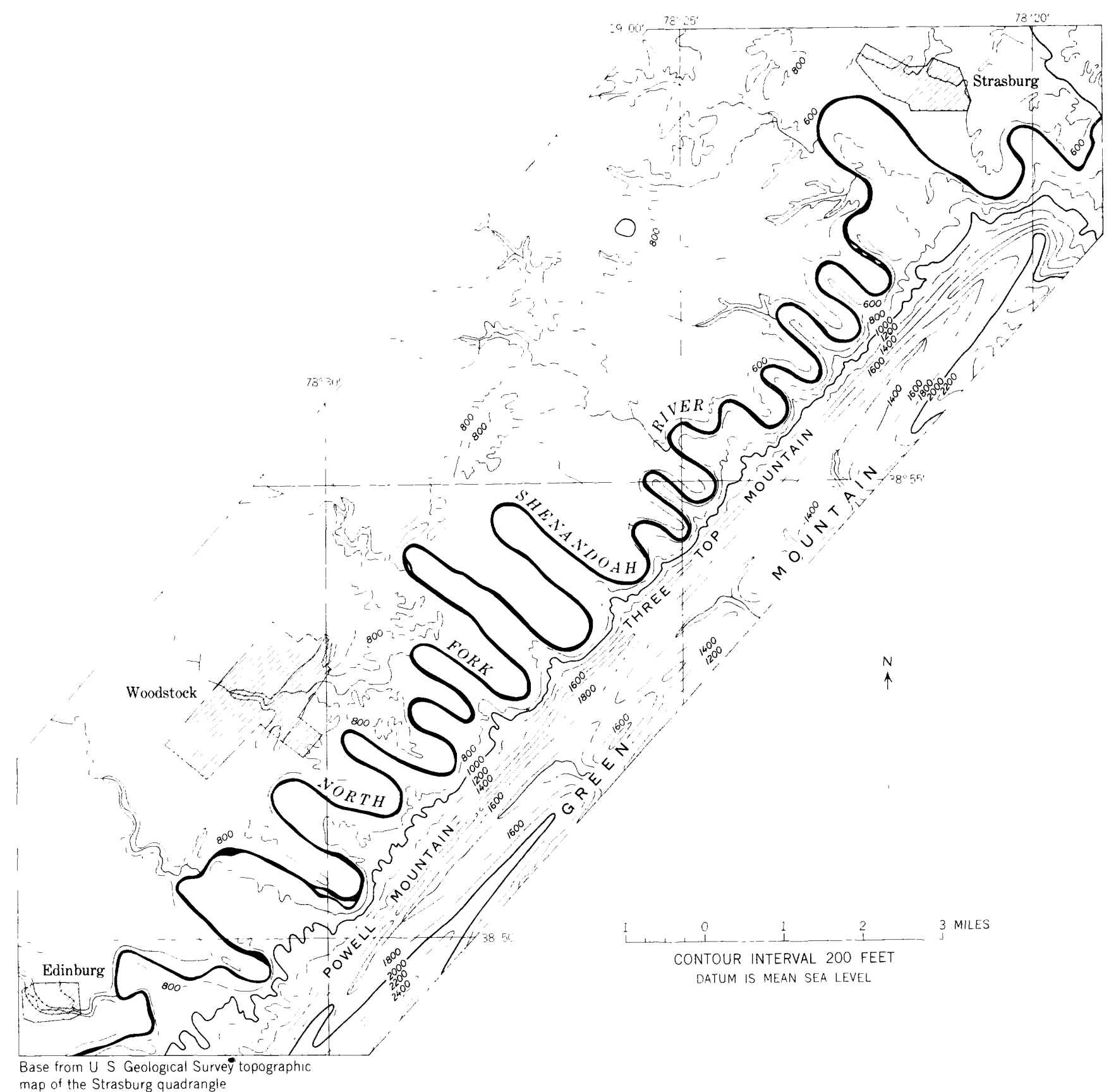

Figure 1.-Map of the meandering reach of the North Fork of the Shenandoah River. Redrawn from the Strasburg, Va., quadrangle of the U.S. Geological Survey (1947).

Edinburg-Woodstock area in 1951-52, and studies of streams by J. T. Hack in the Shenandoah Valley in 1952-57. Measurements of the stream channel were made in 1957. The writers are grateful to colleagues in the Virginia Division of Geology and the U.S. Geological Survey for their suggestions and critical review.

\section{GEOLOGY OF THE RIVER BASIN}

The valley of the North Fork may be divided into three parts, each having distinctive geology, as shown on the map of the river basin, figure 2. The headwater area above Cootes Store is in folded sandstone and shale of Silurian and Devonian age. The interstream divides are steep sandstone ridges rising 1,500 to 2,000 feet above the shale valleys. Along the main streams the valleys are broad and flat floored. The channels are flanked by broad flood plains and gravel terraces. Rock is not exposed in the channels, and the beds and banks are composed of rounded cobbles in imbricate arrangement, derived from the flanking 


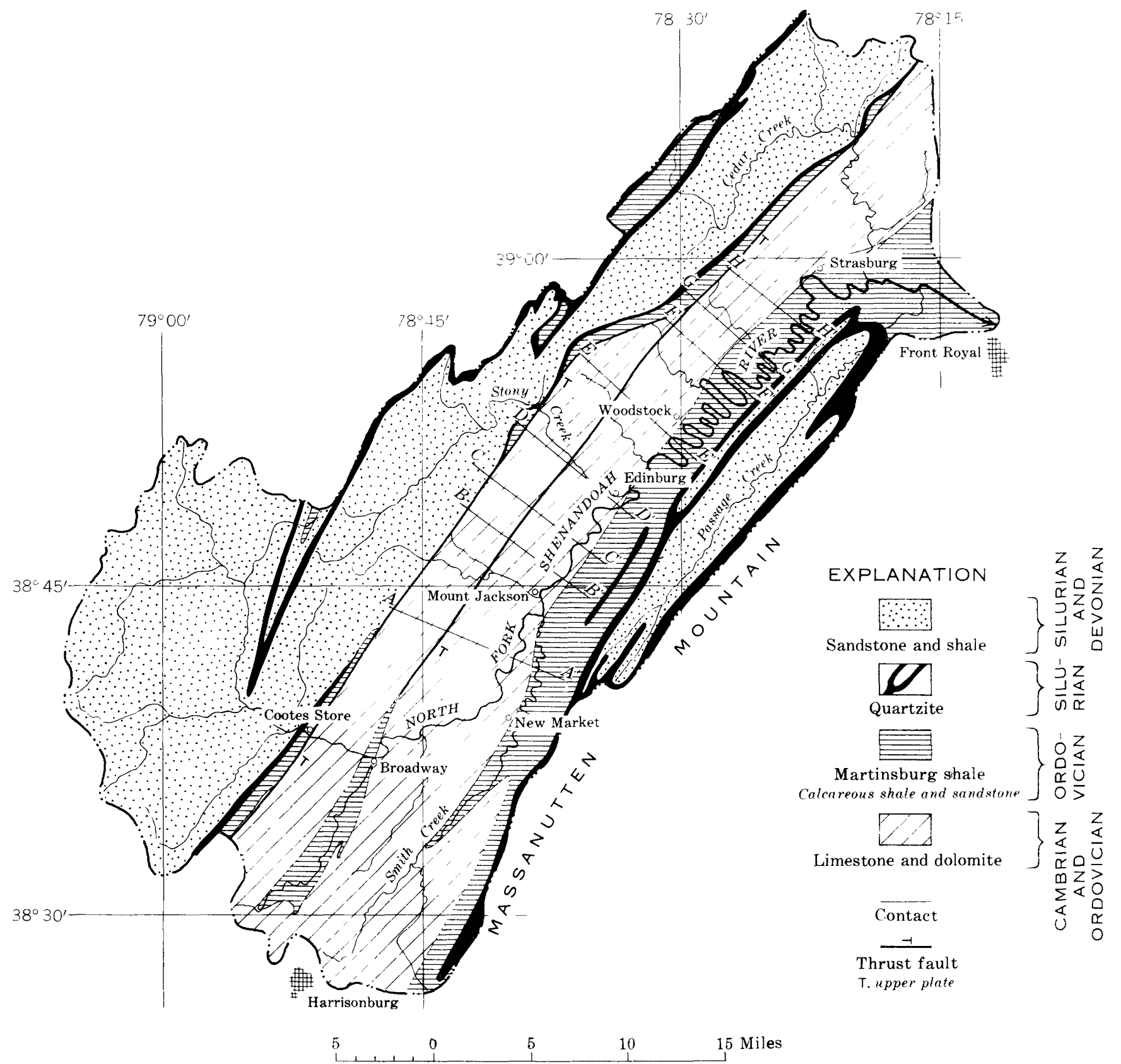

Figune 2.- Simplified geologic map of the drainage basin of the North Fork, Shenandoah River, showing relation of the meanders to the Martinsburg shale, and location of profiles (fig. 5).

sandstone ridges. In the segment of the river from Cootes Store to Edinburg the river crosses the main Shenandoah Valley, a rolling country with an average relief of about 200 feet, that is underlain by Cambrian and Ordovician carbonate rocks. The river is bordered by terraces, narrower than those upstream but nevertheless considerably wider than the channel. In a few places terraces are a mile wide. The width of the flood plain and terraces diminishes, however, in a downstream direction. Banks and bed are composed primarily of cobbles of sandstone transported from upstream. Above Broadway the river crosses the strike of the rocks at right angles. Below Broadway it parallels the strike following closely a belt of limestone at the top of the Cambrian. As far as Mount Jackson it remains on the northwest side of prominent and resistant cherty beds in the Beekmantown dolomite (Ordovician). Just above Edinburg the river crosses the cherty beds and enters a belt of Martinsburg shale.

Below Broadway, outcrops of limestone occur in the bed in many places. From Mount Jackson to Edinburg limestone outcrops are more numerous, and the 
streambed contains angular cobbles and boulders of limestone of local origin equal in number to the sandstone cobbles transported from upstream.

The third distinctive segment of the river is the meandering reach extending from Edinburg to beyond Strasburg. In this segment the river flows on the Martinsburg shale, a tightly folded belt of weak siltstone, fine sandstone, shale, and subordinate calcareous shale, that has a prominent fracture cleavage and joint system oriented northwestward. The river is flanked on the southeast by the steep shale slopes of Massanutten Mountain, a complex syncline. The side of this mountain that borders the North Fork has a core of hard quartzite, of Silurian age, exposed at the crest. The quartzite breaks up in boulders forming talus slides and block fields that extend down the hollows in the mountainside to the meander bends of the river. In contrast to the upstream reaches, the riverbed in the meandering segment is mostly exposed bedrock. Gravel and cobbles occuply less than one third the area of the bed. The channel is bordered by a narrow flood plain and in some places by gravel terraces. In three places the terraces occupy abandoned meander loops 20 to 40 feet above river level.

\section{RIVER CHANNEL}

LONGITUDINAL PROFILE

It is of first importance to consider whether the profile is smoothly graded or whether there is a break in grade, an irregularity, or other change that marks

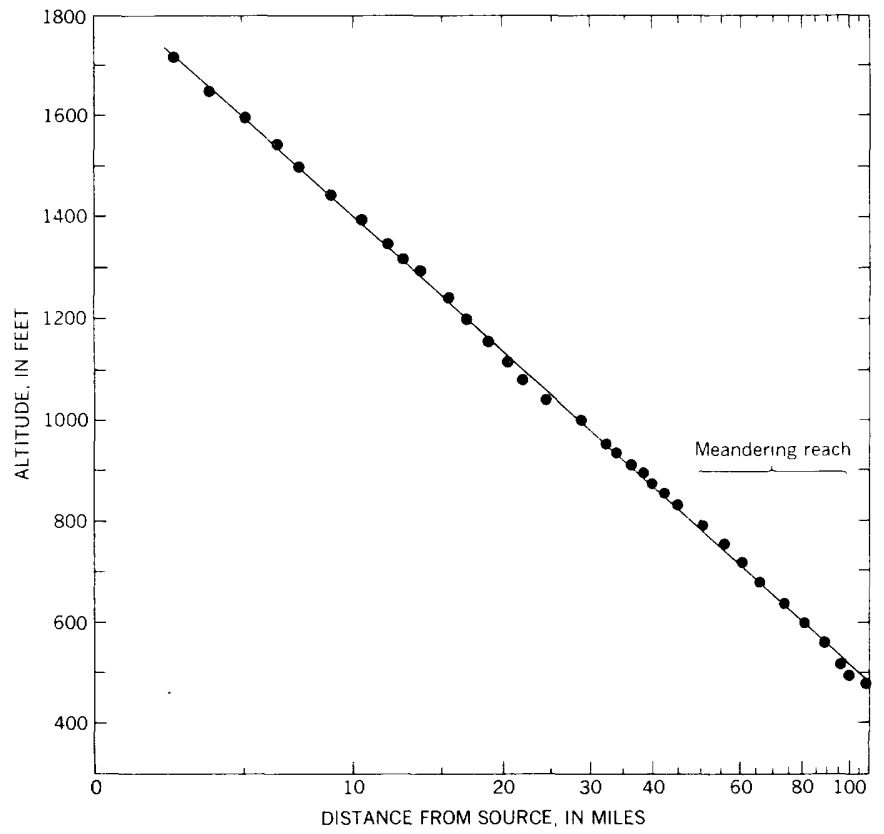

Frgure 3.-Longitudinal profile of the North Fork of the Shenandoah River. The distance from the source is measured along the Iongest or principal stream of the drainage basin which heads on the Virginia-West Virginia boundary at lat $38^{\circ} 40^{\prime} \mathrm{N}$. The horizontal scale is logarithmic. the beginning of the meandering segment. Examination of the profile, measured along its channel, shows that it is uniform. The profile follows fairly closely a simple logarithmic curve, as shown in figure 3, though there are departures from it. It is a property of such a profile that the channel slope $(S)$ at any point on the stream is inversely proportional to the stream length $(L)$ (the distance from the source to the same point.) The ratio of the slopes at any two points $\left(S_{1}\right.$ and $S_{2}$ ) is equal to the reciprocal of the ratio of the lengths of these points $\left(L_{1}\right.$ and $\left.L_{2}\right)$ :

$$
\frac{S_{1}}{S_{2}}=\frac{L_{2}}{L_{1}}
$$

\section{CHANNEL CROSS SECTION}

Channel cross section is a significant factor affecting the adjustment of the stream to its load. If there were changes in the nature of the equilibrium conditions in the channel the cross section might be expected to change. The results of measurements made by traverses with tape and hand level across the channel from flood plain to flood plain are shown in figure 4. The variations within a reach are much greater than the variations between the meandering and nonmeandering reaches. Therefore no significant difference can be shown.

\section{BED MATERIAI}

Rock fragments resting on the bed of the North Fork are coarse throughout and consist of pebbles, cobbles, and boulders. The bed material was sampled at several localities, including two in the lower or meandering segment, two in the middle or limestone segment, and three in the upper segment above Cootes Store. Size was estimated by measuring the intermediate diameters of more than 50 fragments on the streambed selected at regular intervals along a tape stretched across the streambed. The size statistics at these localities are given in table 1.

TABLE 1.-Summary of data on size of fragments on the streambed, North Fork, Shenandoah River

[Results of analyses made in the field by the Wolman method (Wolman, 1954; Hack, 1957)]

\begin{tabular}{|c|c|c|c|c|c|c|}
\hline \multicolumn{2}{|l|}{ Locality } & \multirow{2}{*}{$\begin{array}{l}\text { Number } \\
\text { of frag- } \\
\text { ments in } \\
\text { sample }\end{array}$} & \multirow{2}{*}{$\begin{array}{c}\text { Phi } \\
\text { mean } \\
\text { size }\end{array}$} & \multirow{2}{*}{$\begin{array}{l}\text { Phi } \\
\text { standard } \\
\text { deviation }\end{array}$} & \multirow{2}{*}{$\begin{array}{l}\text { Geomet- } \\
\text { ric mean } \\
(\mathrm{mm})\end{array}$} & \multirow{2}{*}{$\begin{array}{l}\text { Percent } \\
\text { sand- } \\
\text { stone in } \\
\text { sample }\end{array}$} \\
\hline Segment & $\begin{array}{l}\text { Miles } \\
\text { from } \\
\text { source } \\
\text { of river }\end{array}$ & & & & & \\
\hline Upper segment_.... & $\begin{array}{r}7.8 \\
15.4 \\
18.8\end{array}$ & $\begin{array}{l}50 \\
50 \\
52\end{array}$ & $\begin{array}{l}-6.26 \\
-6.64 \\
-6.02 \\
\end{array}$ & $\begin{array}{r}1.45 \\
1.35 \\
.93 \\
\end{array}$ & $\begin{array}{r}76 \\
100 \\
64\end{array}$ & $\begin{array}{l}100 \\
100 \\
100\end{array}$ \\
\hline $\begin{array}{l}\text { Middle segment } \\
\text { (limestone) }\end{array}$ & $\begin{array}{l}46.2 \\
48.2\end{array}$ & $\begin{array}{r}76 \\
103\end{array}$ & $\begin{array}{l}-5.90 \\
-6.00\end{array}$ & $\begin{array}{l}1.40 \\
1.25\end{array}$ & $\begin{array}{l}59 \\
64\end{array}$ & $\begin{array}{l}68 \\
86\end{array}$ \\
\hline $\begin{array}{l}\text { Lower segment } \\
\text { (Martinsburg } \\
\text { shale) }\end{array}$ & $\begin{array}{l}79.5 \\
92.7\end{array}$ & $\begin{array}{r}119 \\
66\end{array}$ & $\begin{array}{l}-5.45 \\
-6.59\end{array}$ & $\begin{array}{l}1.74 \\
1.37\end{array}$ & $\begin{array}{l}44 \\
95\end{array}$ & $\begin{array}{l}37 \\
25\end{array}$ \\
\hline
\end{tabular}




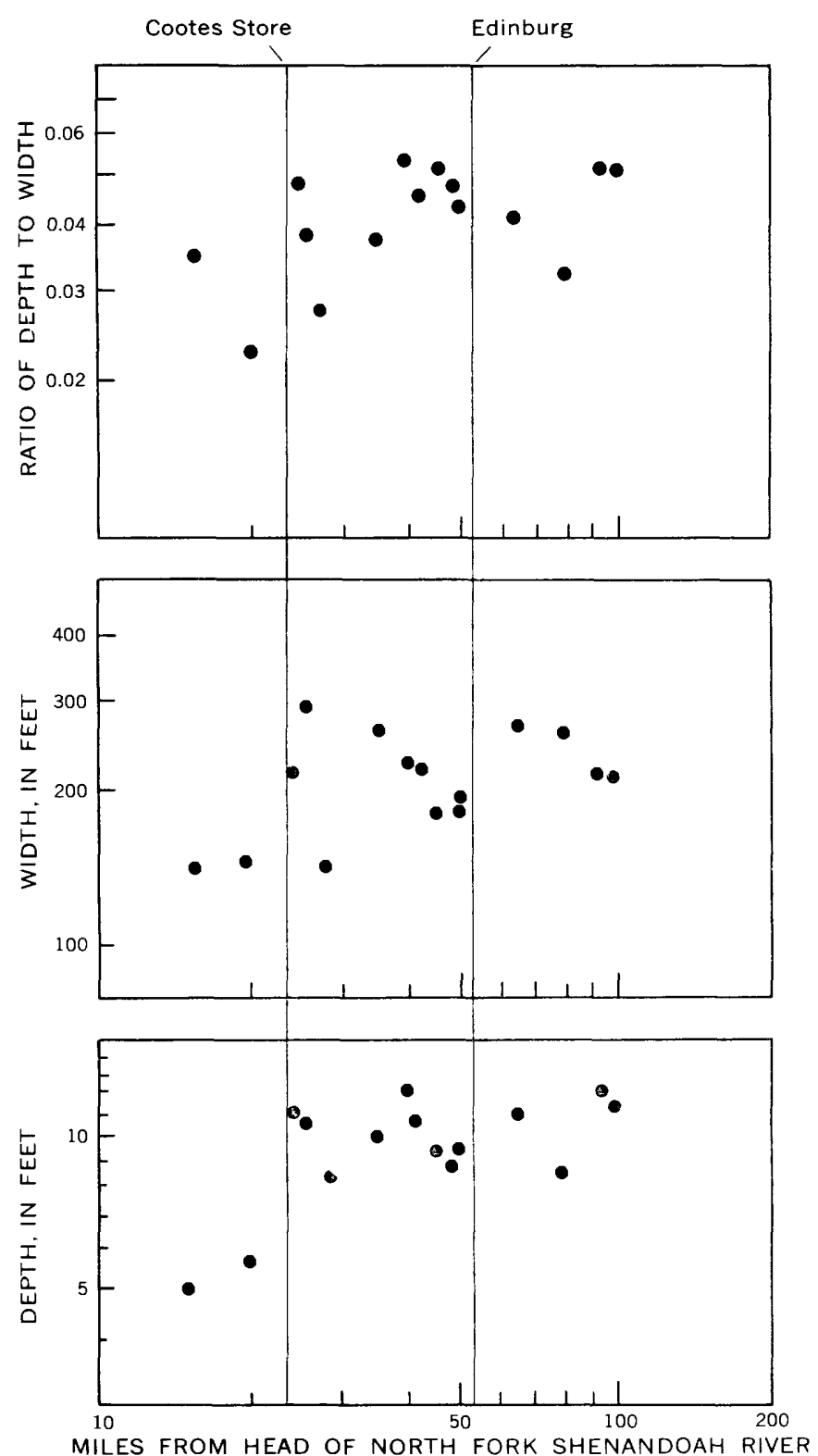

FIgURE 4.-Graph on logarithmic scales comparing the dimensions of the channel of the North Fork at different places along the stream.

These statistics do not apply strictly to the traction load that is moved day by day or month by month. They describe material that is now on the bed, some of which has been moved from upstream, and some of which is residual and represents a lag concentrate of fragments torn off the bedrock locally but that is not yet broken into sizes small enough to have been moved in the last flood. It was shown by studies in other streams in the Shenandoah Valley (Hack, 1957, p. 7687), however, that siliceous rocks like sandstone and chert are moved great distances downstream from their source, whereas rocks like limestone and shale are soft and are not carried far downstream before they are broken into sizes too small to remain as a lag concen- trate on the bed. Inasmuch as the bed samples of the North Fork all contain sandstone from upstream, in addition to locally derived rocks, and the sandstone is on the average coarser than the local rocks, it is inferred that the river is competent to more material of the size that is on the bed.

The sampling indicated no significant change in size of bed material along the stream, as shown by an analysis of variance of the phi mean sizes. The bed material is equally as coarse or coarser near the mouth, in the meandering reach at mile 92.7 , as it is near the source, at mile 7.8. The lack of change of particle size along the stream is related to the regular form of the longitudinal profile. Studies in a wide selection of streams in the Shenandoah Valley and in nearby Maryland and Virginia (Hack, 1957) show that the range in the size of fragments on the streambeds is from mean sizes more than 600 millineters to mean sizes less than 10 millimeters. These size variations are related to differences in discharge, chamnel slope, and to other hydrologic variables as well as to the material itself, and it was shown that streams with the competence to move the material of the same size along their entire course, have longitudinal profiles like that shown in figure 3, of the North Fork. In such profiles the fall is proportional to the logarithm of the length, and the chamel slope is inversely proportional to the length.

The problem is illuminated by consideration of the relative proportions of the materials on the bed. It is noteworthy that in the upper segment the bed material is all sandstone. This is an area of high relief in which many tributaries enter the stream from ridges composed predominantly of sandstone of Silurian and Devonian age. Although the river itself is flowing in a shale valley, the bedrock is so soft, relative to the sandstone introduced by the tributaries, that the bedrock is broken up and carried away in small fragments, and the proportion that remains on the bed is too small relative to the sandstone to appear in the sample. In the middle segment (Cootes Store to Edinburg), where limestone is the dominant bedrock, sandstone on the bed diminishes in relation to limestone. This is because the part of the drainage basin underlain by sandstone diminishes as the basin enlarges in the limestone region. In the lower segment, underlain by Martinsburg shale, the proportion of sandstone diminishes still further, and fragments of Martinsburg shale, although much softer, make up three-fourths of the total material in transit on the bed.

Although not shown in table 1, wherever sandstone bed material is mixed with shale and limestone fragments, the sandstone component is the coarsest. The mean size of all the bed material sampled averages 68 
millimeters. The mean of all sandstone fragments is 78 millimeters, and the mean of all limestone and shale fragments is 59 millimeters. Since sandstone is the most resistant material it determines the size of the other components of the bed material. Fragments of locally derived rock that are much smaller are quickly transported downstream, whereas larger fragments accumulate at their source until they are broken into sizes small enough to be moved by traction. The size of the sandstone fragments must be a function of several factors including inherent properties of the rock, such as its toughness, and the spacing of joints, and of external factors such as the distance from the source and rate of transport. If the sandstone were all derived from the headwater area above Cootes Store the size of fragments on the bed probably would diminish downstream as it does in the Middle River (Hack, 1957, fig. 38). In the North Fork, however, the load of large sandstone fragments transported only short distances is renewed downstream by tributaries like Smith Creek and by rock discharged into the stream from the slopes of Massanutten Mountain.

\section{DISCHARGE}

The North Fork shows a regular increase in discharge as the drainage area becomes larger. Data on the average discharge are available at three gaging stations along the river as shown in table 2 .

TABLE 2.-Mean annual discharge at gaging stations on the North Fork of the Shenandoah River

[Commonwealth of Virginia, Division of Water Resources, 1952]

\begin{tabular}{l|r|r|c}
\hline Location of gage & $\begin{array}{c}\text { Drainage } \\
\text { area } \\
\text { (square } \\
\text { miles) }\end{array}$ & $\begin{array}{c}\text { Length of } \\
\text { record } \\
\text { (years) }\end{array}$ & $\begin{array}{c}\text { A verage } \\
\text { annual } \\
\text { discharge } \\
\text { (cfs) }\end{array}$ \\
\hline Cootes Store & 215 & 25 & 184 \\
Mount Jackson & 509 & 7 & 351 \\
Strasburg .... & 772 & 25 & 568 \\
\hline
\end{tabular}

SUMMARY OF CHANNEL CHARACTERISTICS

The North Fork of the Shenandoah River has a smooth longitudinal profile so regular that it follows closely a simple logarithmic curve throughout its length. Measurement of the bed material indicates that the channel slope and cross section are adjusted with the available discharge so as to transport bed material of the same size. This size is determined in part by the physical properties of sandstone beds of Silurian and Devonian age, the most resistant rocks of the drainage basin. The adjustment of various factors seems to be precise with regard to the bed material and longitudinal profile. This adjustment is maintained throughout the entire river course in spite of great changes in bedrock conditions and in the simuosity of the river.

\section{CONTROLS OF MEANDER FORMATION}

The close correlation of the meanders with the outcrop area of the Martinsburg shale (fig. 2) shows that the meanders are related in origin to this formation. Furthermore, other rivers in the Shenandoah Valley have elongate meanders in the same rock formation. The straight reaches of the North Fork within the meander belt all trend uniformly northwestward, although as reported by Fisher (1955) the river has some short rectilinear reaches less than 1,000 feet long at the bends that trend N. $40^{\circ} \mathrm{E}$.

The Martinsburg shale consists of thin laminae alternately of fine-grained sandstone, siltstone, and shale. Calcareous beds occur at some horizons, particularly near the base of the formation. A typical lithologic unit is exposed in a roadeut shown in plate 1. A section 25 feet thick at this locality contains 8 fine-grained sandstone beds averaging 2.3 feet in thickness and 7 siltstone and shale beds averaging 1.0 feet in thickness. The sandstone beds are notably more resistant to erosion than the shale. In the river channel the fine sandstone beds stand up as slablike corrugations, separated by grooves of shale, in places 2 feet deep. The corrugations are prominent and striking features of the riverbed for long distances, and at low-water periods form straight lines crossing the water surface northeastward at right angles to the channel banks.

The prominent slabs or laminations are cut by a strong joint system in which the most sharply defined planes are alined northwest-southeast. There is also a prominent fracture cleavage. The siltstone beds, in particular, are broken into crude match-shaped prisms whose long axes are oriented northwestward parallel to the principal joint planes. The prismatic cleavage is independent of the bedding. This structure is illustrated in plate 1. Spheroids are common in the Martinsburg, especially in the more massive siltstone beds. These bear no apparent relation to the fracture cleavage, which cuts through them.

Another characteristic of the Martinsburg shale that may favor meander development is its relatively low resistance to erosion. The shale is commonly found in the lowest parts of the valleys and is nowhere a ridge maker.

Examination of the meanders (fig. 1) shows that, unlike alluvial meanders, they consist of long straight reaches connected by $180^{\circ}$ bends. The amplitude of the meanders is irregular and in places is more than twice the value of the wavelength. Alluvial meanders, on the other hand, are more symmetrical. The curves, or ares, that form the bends generally exceed $180^{\circ}$ of 


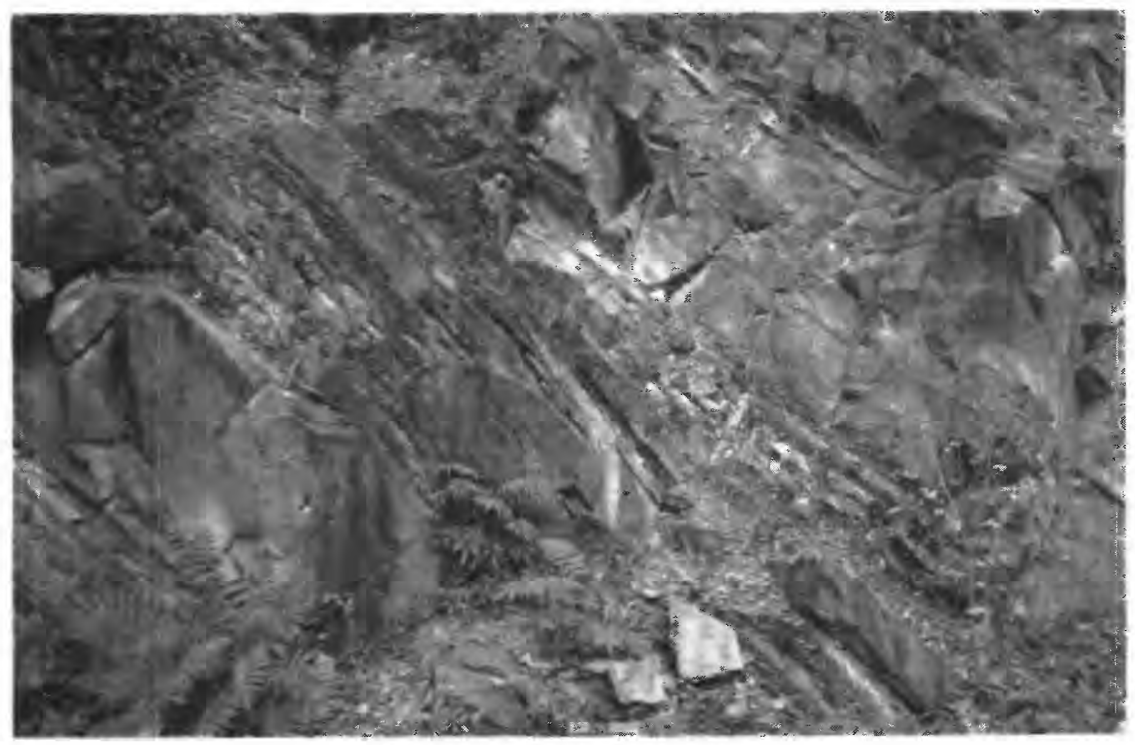

A. OUTCROP NEAR WOODSTOCK

Showing typical beds of fine sandstone and siltstone alternating with shale

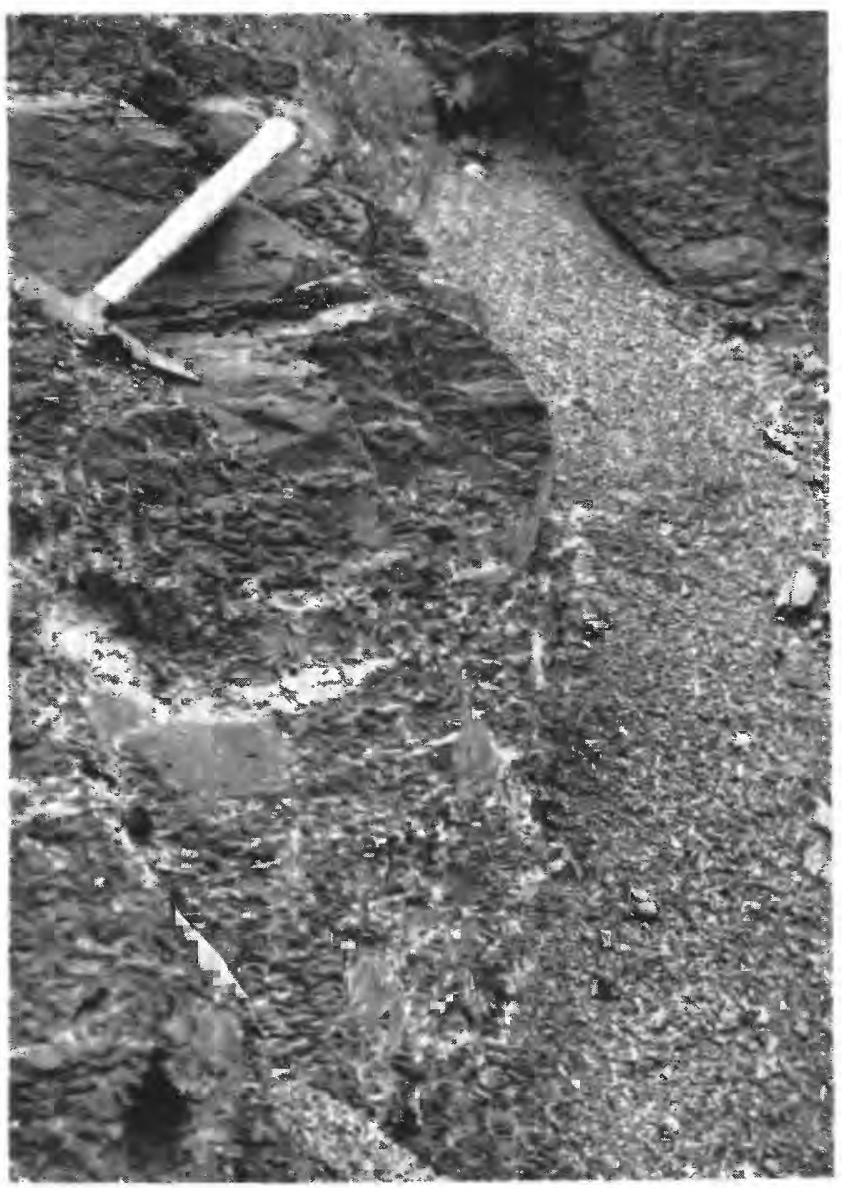

B. OLTCROP NEAR EDINBLRG

Showing typical prismatir cleavage cutting a spheroid. The small talus apron at right is composed of siltstone prisms

OUTCROPS OF MARTINSBURG SHALE 
arc, and the amplitude is regular and may be nearly equal to but rarely larger than the wavelength. In alluvial meanders, crossovers (where the rurrent crosses from one side of the stream to the other) generally occur at the same point on the bends. In the North Fork, crossovers occur not only on the bends but also in the straight reaches. This phenomenon is a consequence of the extraordinary amplitude of the meanders.

The North Fork meanders bear at least one similarity to alluvial meanders, however. Their wavelength is regular and is a function of the discharge or width of the stream. Opequon Creek, for example, and the Middle River, which are smaller streams in the Shenandoah Vailey, have meanders of the same type but the wavelengths are smaller. Leopold and Wrolman (195\%, p. 58) have shown that there is a regular relation between the wavelength of the bends in a strean and the channel width and discharge. Streams with a channel width of 250 feet, like the North Fork, have an average meander wavelength of about 3,000 feet. The wavelength of the North Fork meanders is $t, 000$ feet which is in agreement with Leopold and Wolman's data, considering the range in variation.

In summary it has been shown that the North Fork has throughout its length just the slope and cross section required with the gradually increasing discharge to transport the more resistant rock fragments eroded in the drainage basin. The extraordinary elongate meanders are formed in the least resistant rock of the drainage basin and follow closely planes of structural weakness in that rock. In the upstream reaches the riverbed is mostly covered by cobbles and boulders, whereas in the meandering reaches the bed is mostly on exposed bedrock. The river travels a much greater distance within the meandering reaches for a given downvalley distance than it does in the nonmeandering reaches, and a larger proportion of the valley floor is occupied by stream channel.

The explanation for the meanders, then, is that in the Martinsburg shale the river chamel was cut along lines of structural weakness in the rock while the slope and cross section necessary to transport cobbles and boulders derived from upstream or from trihutaries was maintained. The lesser amount of sandstone and other transported cobbles on the bed suggests that in the meandering reaches, greater energy has been expended in the excavation of rock by elongation of the channel and less by the transportation of rock fragments. Instead of a bed composed largely of cobbles the river has a bed mostly of shale arranged in projecting laminae that resemble a washboard. These projections may supply a frictional resistance to streamflow similar to the resistance supplied upstream by gravel and cobbles and thus maintain the equilibrium of grade and cross section. Spacing of the meanders, as shown by a comparison with typical alluvial meanders, is a function of hydrologic factors rather than factors related to the bedrock.

\section{INTRENCHMENT HYPOTHESIS}

The argument in the preceding pages disposes of the hypothesis of meander origin suggested by Charles Butts (1940, p. 508), which supposes that the meanders are inherited from allurial meanders formed on a peneplain and that they have been preserved but modified in shape as the river was rejuvenated during a postulated Pleistocene regional uplift. The meanders are coincident with the outcrop area of the Mart insburg shale, and are related in origin to structural properties of that formation rather than to an alluvial deposit that has been removed.

It has been noted by many geologists, however, that the Yorth Fork is bordered by steep valley walls, and the stream has often been referred to as intrenched, or entrenched (for example 'Thornbury, 1954, p. 146. fig. (6.2). The word "intrenched" itself implies that the river has cut down through bedrock in a narrow valley but that at one time it flowed across a more open plain such as a peneplain or at least an open valley less narrow than the present one. If this were the case prestmably the meanders dere]oped during intrenchment.

The topography adjacent to the river is now considered to determine whether the intrenchment hypothesis is necessary in explaining the valley. Figure 5 shows a series of transverse profiles across the Shenandoah Talley from Massanutten Mountain to the sandstone ridges on the northwest. Protiles $A-A^{\prime}$ to $I-I)^{\prime}$ ('ross the valley in the limestone area above the meandering reaches of the river, whereas profiles $E-E^{\prime}$ to $I I-I I^{\prime}$ cross the meanders. The topography as illustrated by these profiles is hilly and irregular. It is not feasible on the basis of this topography to reconstruct is hypothetical peueplain or erosion surface of low relief. The hilltops are too irregular in altitude and in relative height above the streams. Furthermore, study of the geology of the area shows that the height of the hills is closely related to their lithologic composition. The high hills in the western part of profile $A-A^{\prime}$, for example, are underlain by limestone containing thick beds of chert. If the area ever were a peneplain its surface nust have been above the present topography.

The narrow, bedrock valley of the North Fork typified by the cruss section $H-\Pi^{\prime}$ (fig. 5) is adeqnately explained without recourse to the idea of peneplanation or a surface of low relief. The topography along the North Fork is an equilibrium or graded topography 

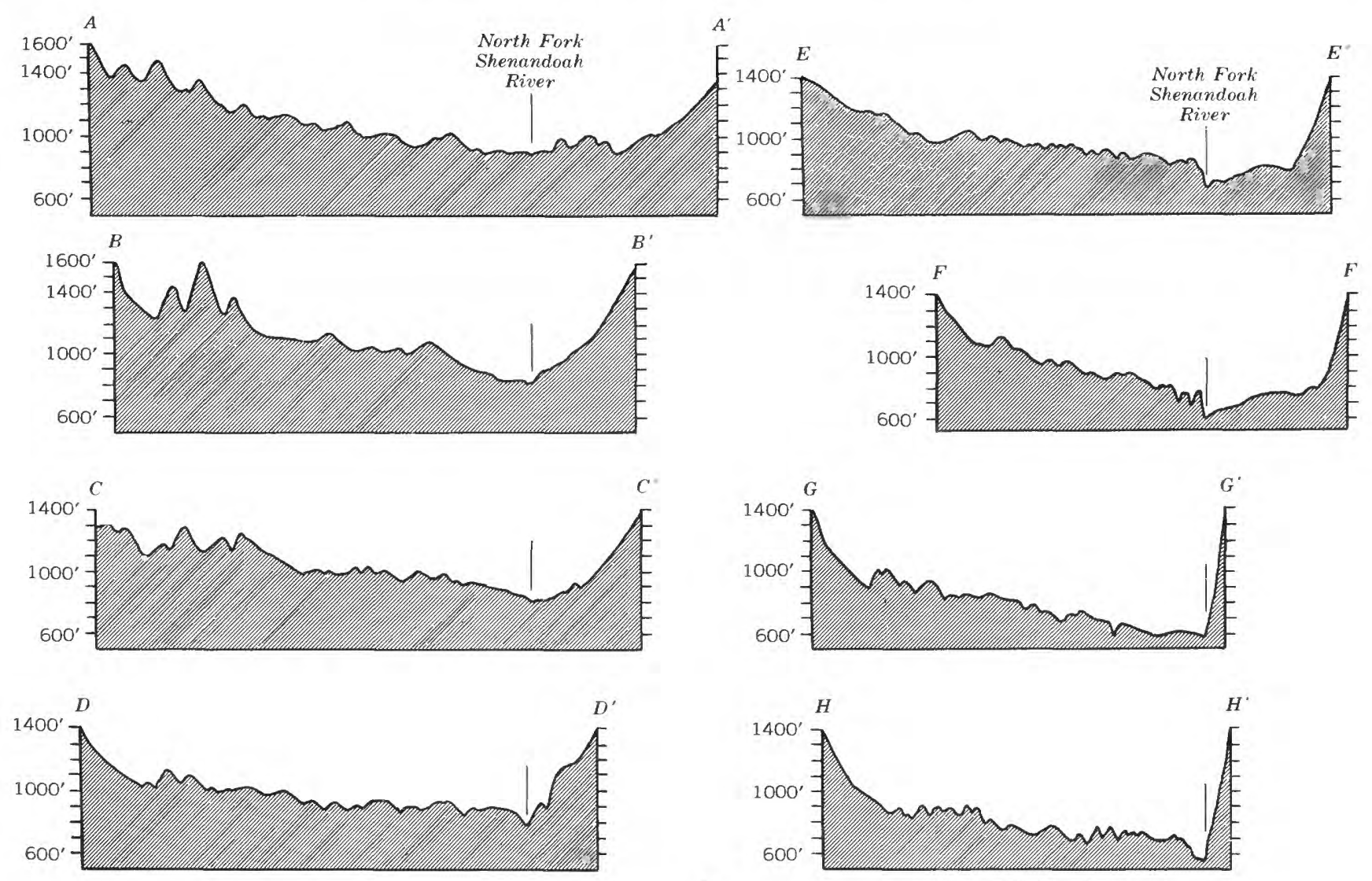

L

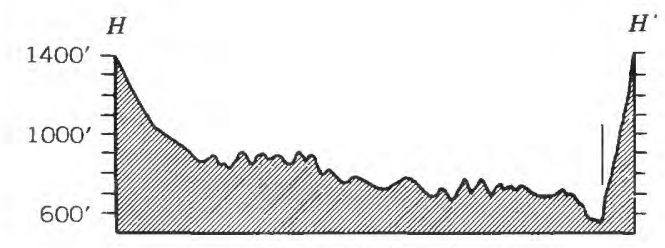

10 MILES

DATUM IS MEAN SEA LEVEL

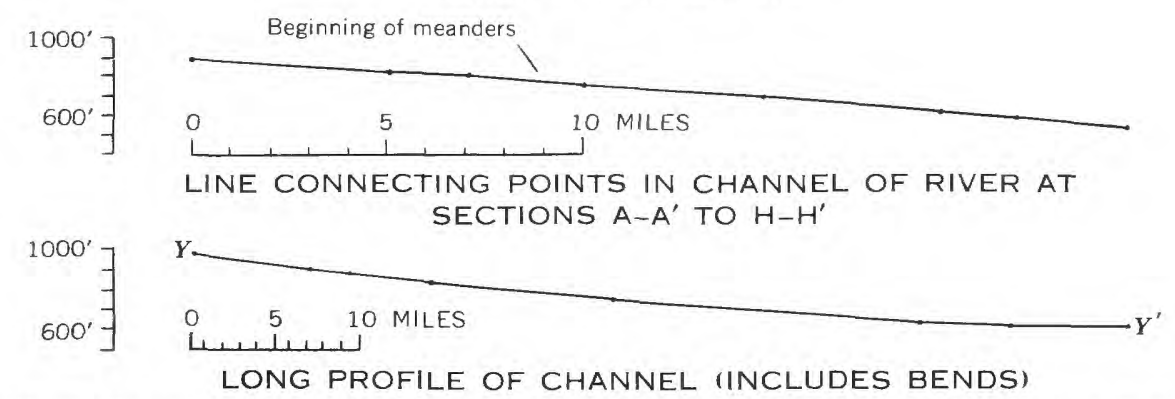

Figure 5.--Profiles with greatly exaggerated vertical scale showing the relief of the floor of the Shenandoah Valley in the outcrop area of Cambrian and Ordovician limestone and shale. The location of the profiles is shown on figure 2.

like that described by Hack and Goodlett (in press, 1960) in an area nearby, or by Strahler (1950) in the Verdugo Hills, California. As shown by many recent geomorphological works, principally that of Horton (1945), drainage networks are characteristically regular in pattern and the density of drainage of streams of the same order tends to be nearly constant in areas of the same climate and geology. As a consequence the interstream divides form a system of ridges rising above the streams about the same height. A large trunk stream in such a network of valleys and ridges appears to be intrenched because it is bordered mostly by the steep slopes of interstream areas. These slopes are graded for the transportation of soil and rock fragments by the process of creep, and hence are convex upward. The streams that intersect the trunk streams are mostly first-order streams and they intersect at a high angle. The appearance of intrenchment is enhanced if the topography is underlain by a nonresistant rock on which the profiles of the interstream areus are convex upward and therefore appear rounded or flattish.

Such a topography may be said to be composed of slopes that are everywhere in a state of continuous 
adjustment so that the materials weathered and eroded from the surface are transported through a network of chamnels into larger and larger trunk streams. Depending on the rate of erosion and the total relief, the average slopes of such a topography may be very steep or very gentle.

The longitudinal profile of the North Fork shown at the bottom of figure 5 by the line $Y-I^{\prime \prime}$, is drawn along the channel and includes the bends of the meanders. It is a smooth curve, gently concave upward and is of simple form because adjusted to transport material of the same size with a gradually increasing discharge. The profile above it (that has a larger horizontal scale) connects points in the river channel along a nearly straight line. It does not include the meander bends and therefore represents the profile, as the crow flies, drawn along the lowest points of the valley bottom. This curve is steeper in the meandering reaches than in the reaches upstream. The adjacent network of tributary channels and intervening hills are graded to the main trunk channel, and therefore the entire topographic surface adjacent to the North Fork has a downvalley or northeastward component of slope that is steeper in the meandering region than in the part upstream.

If the topography adjacent to the North Fork can be satisfactorily explained as a graded topography or a topography in which the erosional slopes are in equilibrium, then the meanders exist simply because they are in the Martinsburg shale, and we can expect that any river of comparable size with the gradient necessary to transport cobbles and boulders will also meander in the Martinsburg. An exception to this generalization would be a stream so heavily loaded with waste of material derived from upstream that the bed and banks would be blanketed by this material thereby insulating the river from the shale.

It becomes pointless to speculate on the geologic history of the North Fork and the manner in which it has cut down into the Martinsburg. The river may have eroded its way downward in the northwest limb of the Massanutten syncline thousands of feet, and may have developed and maintained a meandering course in the Martinsburg shale in the distant geologic past.

\section{MEANDERING STREAMS IN ROCKS OTHER THAN THE MARTINSBURG SHALE}

Meandering streams of the Shenandoah type are common in the central Appalachians, and they are not all confined to the Martinsburg shale. Meandering reaches are spectacular in the Middle River, Augusta County, Va., in Cambrian limestone. The Potomac
River has well-dereloped meanders that are apparently structurally controlled in rocks of Devonian age. Meanders almost as striking as those in the Martinsburg shale occur in southwestern Virginia in metamorphic rocks on both sides of the Blue Ridge escarpment. The Nerr River, Reed Island Creek, Dan River, and Blackwater River, for example, display meanders with extreme amplitudes. The meanders of the Dan, like the meanders of the North Fork, are confined in strongly laminated rocks, although the rocks are metamorphic with alternating thin layers of quartz mica schist and amphibolite schist.

\section{CONCLUSION}

The meanders of the North Fork have been explained within a framework of ideas in which rejuvenation and a former surface of low relief are not factors. In the writer's' hypothesis the meanders are an essential part of a graded, erosional topographic system. The arrangement of the rocks in space and the action of hydrologic factors on them is the basis for our explanation of the topography and pattern of drainage, rather than a change in regimen or slope resulting from an uplift.

The elevation of the mouth of the North Fork is determined largely independently of conditions in its own drainage basin, for it empties into a much larger stream, the South Fork, which determines the local base level. The elevations of the headwaters of the North Fork are also to some extent determined independently for they are related to the physical and chemical resistance of the rocks under the drainage divides. Between these two independently fixed points the profile of the stream is determined by a combination of factors, some local-related to the rocks along the channel-others related to duties imposed from upstream such as quantity of water and size and amount of bed material. The meanders result from the interaction of these factors with those of local origin related to peculiar structural properties of the enclosing rock.

Leopold and Wolman (195\%), dealing primarily with streams flowing in alluvial channels, have demonstrated a close relation between hydrologic factors, including channel slope, discharge, and load, that apparently determine whether or not a stream will meander. It seems from our data and analysis that the meanders of the North Fork, even though in bedrock, exist in harmony with the same kinds of factors. Probably streams that meander in bedrock are actively eroding streams that have a relatively small load for the slope and discharge and that erode weak rocks with strong linear and planar structures. 


\section{REFERENCES}

Butts, Charles, 1940, Geology of the Appalachian Valley in Virginia: Virginia Geol. Survey Bull., v. 52, 568 p.

Cole, W. S., 1930, The interpretation of intrenched meanders: Jour. Geology, v. 38, p. 423-436.

Commonwealth of Virginia, Division of Water Resources, 1952, Surface water supply of Virginia, Potomac, Rappahannock, and York River Basins, 1942-50: Commonwealth of Virginia, Dept. of Conserv. and Devel. Bull. 12, 372 p.

Fisher, C. C., 1955, Elongate meanders of the North Fork of the Shenandoah River [abs.]: Geol. Soc. American Bull., v. 66, p. 1687 .

Gregory, H. E., and Moore, R. C., 1931, The Kaiparowits region; a geographic and geologic reconnaissance of parts of Utah, and Arizona: U.S. Geol. Survey Prof. Paper 164, 157 p.

Hack, J. T., 1957, Studies of longtitudinal stream profiles in Virginia and Maryland: U.S. Geol. Survey Prof. Paper 294-B, p. 45-97.

Hack, J. T., and Goodlett, J. C., (1960), Geomorphology and forest ecology of a mountain region in the central Appalachians: U.S. Geol. Survey Prof. Paper 347, in press.
Hortou, R. E., 1945, Erosional development of streams and their drainage basins; hydrophysical approach to quantitative morphology: Geol. Soc. American Bull., v. 56, p. 275-370.

Leopold, L. B., and Wolman, M. G., 1957, River channel patterns : braided meandering and straight: U.S. Geol. Survey Prof. Paper 282-B, p. 39-84.

Monuett, V. E., and Brown, H. E., 1950, The principles of physical geology : Boston, Ginn \& Co., 450 p.

Rich, John L., 1939, A bird's eye cross section of the Central Appalachian Mountains and Plateau, Washington to Cincinnati; Geog. Rev., v. 29, p. 561-586.

Strahler, A. N., 1946, Elongate intrenched meanders of Conodoguinet Creek, Pa.: Am. Jour. Sci., v. 244, p. 31-40.

- -1950 , Equilibrium theory of erosional slopes approached by frequency distribution analysis: Am. Jour. Sci., v. 248, p. 673-696 and 800-814.

Thompsol, H. D., 1947, Fundamentals of earth science: New York, John Wiley \& Sons, 618 p.

Thornbury, W. D., 1954, Principles of geomorphology: New York, John Wiley \& Sons, $618 \mathrm{p}$.

U.S. Geological Survey, 1947, Strasburg quadrangle, Virginia, scale $1: 62,500$, shaded relief.

Wolman, M. G., 1954, A method of sampling coarse riverbed material: Am. Geophys. Union Trans., v. 35, p. 951-956. 